\title{
Evolutionary antagonisms and the progress of three categories of traits
}

\author{
Nasser Zakariya* \\ Department of Rhetoric, University of California, Berkeley \\ *Corresponding author: Nasser Zakariya, Email: zakariya@berkeley.edu
}

\begin{abstract}
Darwin in The Descent of Man deliberates over the question of progress in relation to three categories of traits - aesthetic, moral and intellectual - attending to their interplay. The later formulations of Thomas Henry Huxley and Alfred Russel Wallace shift and reframe the terms for weighing together progress and the relationship across these traits, downplaying the role of aesthetic assessments. Huxley and Wallace invoke 'antagonisms' countering, respectively, 'ethical progress' and 'cosmic process', 'humanity - the essentially human emotion' and 'physical and even intellectual raceimprovement'. Thereafter, evolutionary antagonisms reappear - whether to endorse, dismiss or overcome them - and they remain relevant in evolutionary arguments, whether made explicit or left implicit. Following a thread of ongoing appeals to this interplay of traits and corresponding antagonisms invoking Huxley's 1893 lecture 'Evolution and ethics', implicit differences appear in the treatment of aesthetic, moral and intellectual development. These treatments maintain the progress that their own ethical systems represented, even while granting moral variation and conceding independent/alternative notions of the beautiful. They generally took as granted the uniformity of intellectual judgements, where evolutionary progress was both ethical and intellectual/ scientific, even when speculating on the development of different types of mind. As characteristic of future-oriented visions of progress by the first decades of the twentieth century, sexual selection was subsumed under natural selection.
\end{abstract}

This paper responds to a call to 'revisit the implications of evolutionary theory for understanding the diversity of humanity past and present' on the occasion of the 150th anniversary of the publication of Darwin's Descent of Man, querying how 'to reconceive Darwin's legacy if we follow Descent from its roots to its fruits'. This is a challenging call. To provide a sense of relevant context for the late nineteenth century of Darwin's Descent, for example, risks reducing the judgement of an evolutionary legacy beyond that time to ellipses, to vague causal claims, or to quick comparisons with the present. On the other hand, to attempt to sketch a trajectory of intellectual labour risks producing an unmoored history of ideas.

Descent's legacy is particularly thorny. As Evelleen Richards notes, despite the work being the 'culmination of a lifetime of intellectual effort and commitment', the main

(C) The Author(s), 2021. Published by Cambridge University Press on behalf of British Society for the History of Science. This is an Open Access article, distributed under the terms of the Creative Commons Attribution-NonCommercial-NoDerivatives licence (http://creativecommons.org/licenses/by-nc-nd/4.0/), which permits non-commercial re-use, distribution, and reproduction in any medium, provided the original work is unaltered and is properly cited. The written permission of Cambridge University Press must be obtained for commercial re-use or in order to create a derivative work. 
focus of Descent, sexual selection, 'never quite made it'. ${ }^{1}$ Richards points to the 'significant differences between sexual selection as Darwin conceived it and as it is currently understood in evolutionary biology', differences which 'help to explain its long hiatus as well as to illuminate the social and cultural contingencies of the history of a significant, if controversial, biological concept'. ${ }^{2}$ At the same time, Erika Milam argues, 'Although biologists' interest in sexual selection did wane for much of the twentieth century, interest in female choice remained strong'. ${ }^{3}$ Despite the ongoing work on female choice, the self-serving 'historical packaging of sexual selection and female choice' by later biologists effaced that earlier interest. ${ }^{4}$ Contingencies, hiatuses and erasures have shaped the legacy of Descent, reinforcing how complicated is the history of the reception of Darwin's thought.

Here, I hazard a footnote to this scholarship in two overlapping parts. First, I return to textual or rhetorical deliberations over how much natural selection can and should explain. I emphasize a pattern of reflection within deliberations bearing on this concern, a pattern of explicit and implicit assessments of intellectual, moral and aesthetic traits. The concern with these three categories of traits and their assessment are at play in Descent and are evident in the involuted ways in which the idea of progress was at stake in the work. They were at play as well in the contemporaneous and later writings of Alfred Russel Wallace. With the conspicuous exclusion of aesthetic traits, the argumentation extends to Huxley's famed 1893 Romanes Lecture, 'Evolution and ethics'. And with his later 'Prolegomena', Huxley addressed the apparently paradoxical opposition between cosmic and ethical 'processes'.

Despite a not uncommon presumption of correlation between beauty, morality and intelligence, these deliberations generally treated the grounds for assessments of beauty as subject to more variation than those of morality, and the grounds for moral assessments as more subject to variation than those of intelligence. At the same time, that discourse generally omitted an explicit explanation of why - if intelligence, morality and beauty are all subject to evolutionary development - the grounds for their assessments should vary. A beautiful face or form might signal probity and intelligence to Darwin, his contemporaries and some successors. ${ }^{5}$ But the admission of a savage's alternative standard of beauty did not so easily extend to the admission of a thoroughly alternative, independent type of morality, or to any alternative type of intelligence with alternative standards for its assessment.

In the second part of this essay I shift attention to 'Evolution and ethics', emphasizing how 'revisionist' history has clarified its connection to Descent. Thereafter, I briefly canvas references to the lecture appearing as late as the 1940s by prominent evolutionary figures such as J.B.S. Haldane and Julian Huxley, and their interlocutors. Though the first part focuses more on argumentation specific to and drawn from Descent, the second part helps to bring out reverberating patterns of argument over traits with greater clarity. Additionally, the two parts together further suggest how responses to argumentation in and relating to Descent could bracket sexual selection and recast it in such a way as to subsume sexual to natural selection.

Approaching the question of a legacy along these lines, I want to stress that my effort is not to understand elements of Descent or of Huxley's address, or the few other texts taken up here exclusively or primarily through their authors, nor to understand the authors

1 Evelleen Richards, Darwin and the Making of Sexual Selection, Chicago: The University of Chicago Press, 2017, p. xviii.

2 Richards, op. cit. (1), p. xxix, see also 525-36.

3 Erika Milam, Looking for a Few Good Males: Female Choice in Evolutionary Biology, Baltimore: Johns Hopkins University, 2010, p. 2.

4 Milam, op. cit. (3), p. 2.

5 Richards provides extensive evidence of this relevant to the formation of Darwin's opinions. 
through their rhetorics. The historical scholarship of Michael S. Helfand, Richards and others demonstrates how much later readers have not appreciated 'original' meanings, indicating in turn how the reading practices of later generations did not look to historical context to understand a text. The theoretical arguments of Huxley in 'Evolution and ethics' were influential precisely through reinterpretations, including ones predicated on misreadings by the lights of the original context. Misreadings are productive of legacies.

Ideas pertinent to rhetorical and textual legacies form a part of the examination of evolutionary discourse generally. This is evident in the work of scholars such as Gillian Beer, Gowan Dawson, Adrian Desmond, George Levine, Bernard Lightman, James Moore, Angelique Richardson and Helfand, among others. Likewise, discursive analysis forms one aspect of Richards's more recent, expansive treatment of Descent, as it does of Milam's treatment of Descent's scientific legacies. Though this scholarship attends to a far wider legacy than the deliberation I trace here, and to a broader conceptualization of discourse than any evident in my narrow appeal to it, my analysis is informed by this work and largely follows on it. It is scholarship repeatedly demonstrating that discourse and deliberation do not alone constitute a legacy. At the same time, the attention these scholars give to analysis of text and argumentation suggests how discourse may maintain and sustain a theory in such a way as to make a legacy of a theory visible and even viable.

Though this is not the place for a direct argument that 'words matter', it is worth noting that historical work cannot simply presume that arguments through words do not matter - that they are simply reflections and not forceful in themselves. ${ }^{6}$ Treating the legacies of Darwinian arguments exclusively in reference to the motivation, character and times of authors launching these arguments threatens not only to obscure the social resonance of evolutionary theorization thereafter but also, ironically enough, to portray the arguments of historians as more autonomous (as less in need of decoding by reference to a specific context) than the scientific work the historians study.

\section{Descent, decline and progress}

Descent elaborates on how much natural selection can and cannot explain. The familiar concerns seek to find humanity's place in evolution and determine whether or not humanity, or the human mind, constitutes an exception. Discussions about Descent involved the relationship between natural and sexual selection, such as whether the latter was best understood as a corrective supplement to natural selection. This is a point Darwin countered early in Descent:

it has been said by several critics, that when I found that many details of structure in man could not be explained through natural selection, I invented sexual selection; I gave, however, a tolerably clear sketch of this principle in the first edition of the Origin of Species, and I there stated that it was applicable to man. ${ }^{7}$

Darwin did not challenge that natural selection had limits; he challenged that sexual selection was contrived.

Concerns with the range of natural and sexual selection were related to intellectual, moral and aesthetic human traits, appealing to moral and intellectual progress, and to varying standards of beauty. That notion of progress tended to assert a standard that was at its most inflexible with regard to assessments of intellect - including in the details

6 For an explicit argument in this regard see Suman Seth, Difference and Disease: Medicine, Race, and the Eighteenth-Century British Empire, Cambridge: Cambridge University Press, 2018, p. 16.

7 Charles Darwin, The Descent of Man and Selection in Relation to Sex, 2nd edn, London: John Murray, 1874, p. vi. 
of the arguments in Descent regarding reasoning and survival advantages - and was more problematic (in tension with itself) with regard to moral assessments.

A number of commentators view Descent as worthy of particular attention in relation to progress, despite judging its views on the question of 'Man' as rather lacklustre. Historian Greta Jones, for example, claims that 'Darwin had a disruptive effect upon the existing ideologies of social life', an effect that 'became more significant when Darwin undertook to explain human evolution in the Descent of Man'. ' Jones also observes, 'Whilst little of it was original and it brought together materials and explanations which were already available, it passed into intellectual life as Darwinism applied to man and, as such, directly influenced a number of thinkers'. ${ }^{\prime}$ It is worth emphasizing here that Jones does not merely accept or assume Darwinian influence. Rather, she attests and to no small degree endorses arguments warning against overstating the role of Darwin in social and other thought. Fifteen years thereafter, Michael Ghiselin finds similarly that, "especially in The Descent of Man, Darwin was more willing to speculate about progress and related topics'. Ghiselin points to a shift in Darwin's thought, claiming that, as he aged, Darwin became 'increasingly optimistic about the future' because he 'wanted progress to occur'. ${ }^{10}$

Differing conceptions of progress have also been linked to varying assessments of the limits of natural selection's explanatory power. Philosophers such as Joel Schwartz and Michael Ruse (perhaps even Jones) point to Wallace's critiques of sexual selection and his treatment of the limits of natural selection as a prompt for Descent, just as Wallace's letter to Darwin about natural selection had prompted the publication of Origin. Richards deepens and extends the evidence in this regard, dramatizing Wallace's later 'volte face' on female choice and the progressive vision it heralded. ${ }^{11}$

At the same time, as Milam observes, the special role of sexual selection for humanity might undergird moral progress as theorized through and in critique of contemporaneous notions of family and state. ${ }^{12}$ For Darwin, the continuities between human and animal mind and condition, and the assertion of sexual selection as at play across the animal kingdom, produced the possibility of 'improvement' even as they entertained concerns about biological and social decline.

Extensive historical analysis has demonstrated the social roots of such evolutionary declension. Despite the anxieties aired by Darwin, Galton or others, and despite proposals for progress in the face of apparent or immanent decline or in attempts to accelerate reform, this discourse generally held that, due to civilization, the present largely improved on the past, and that here was generally better than there. Yet, as Suman Seth argues in interpreting Darwin's positive comparison of apes over 'savages' through the anthropological sources upon which Descent depended, a kind of lapse was at work within this discourse:

Morally speaking, humankind's half-animal forebears were dramatically better than their later descendants, for earliest 'man' had 'been guided more by his instinctive passions and less by foresight and reason' [citing Descent] ... In a text that emphasized

8 Greta Jones, Social Darwinism and English Thought: The Interaction between Biological and Social Theory, Brighton: Harvester Press, 1980, pp. 8-9.

9 Jones, op. cit. (8), p. 10.

10 Michael T. Ghiselin, 'Perspective: Darwin, progress, and economic principles', Evolution (December 1995), 49 (6), pp. 1029-37, 1030.

11 E.g. Richards, op. cit. (1), p. 401, for 'volte face'. Much of Chapters 12 and 13 argues for the signal role of Wallace as a prompt for the work and the structure of Descent. See also Michael Ruse, 'Sexual selection: why does it play such a large role in The Descent of Man?', in Thierry Hoquet (ed.), Current Perspectives on Sexual Selection: What's Left after Darwin?, Dordrecht: Springer, 2015, pp. 3-17; and Joel Schwartz, 'Darwin, Wallace, and the "Descent of Man", Journal of the History of Biology (Summer 1984) 17(2), pp. 271-89.

12 Milam, op. cit. (3), e.g. pp. 24-5. 
naturalistic explanation, denying literal interpretations of Biblical narratives, and stressing humanity's rise, rather than its decline, Darwin had recapitulated the Fall. Once decent, like lower animals, humanity had gained in reason and lost in morality. ${ }^{13}$

And this in contradistinction to Wallace, who 'saw it [the savage state] as a triumphant rise, a step on the way to a human utopia'. ${ }^{14}$

A number of points should be emphasized here. Concessions that progress was not inevitable, or of the positive state of noble savages or their society, might only strengthen claims that progression was largely the rule. Evolutionists could dispense with apparent contradictory evidence as applying only in a minority of cases, or as hints of a still-better future. Paralleling this, as Seth observes in the case of Lubbock, universalizing judgments could be 'leavened with a touch of relativism'. ${ }^{15}$ This was particularly so in the case of aesthetic traits, and even to a degree moral ones.

Descent is a case in point. There was the claim on the one hand that it is "certainly not true that there is in the mind of man any universal standard of beauty with respect to the human body'. ${ }^{16}$ On the other hand Darwin at least partially conceded shifts in mores if not moral standards: 'Slavery [so detested by Darwin], although in some ways beneficial during ancient times, is a great crime; yet it was not so regarded until quite recently, even by the most civilized nations'. ${ }^{17}$ This in turn (following aesthetic and moral standards) raised the question of the assessment of intellectual standards, whether they were universal, together with their manifestation in the development of evolutionary science.

This question goes to the heart of the reasoning in Darwin's arguments. The fourth and fifth chapters of Descent spoke repeatedly to the relationship between moral and intellectual standards and assessments, calibrating or judging the one through the other. Hence, following an observation on the pain entailed by a breach in etiquette, Darwin noted,

The judgment of the community will generally be guided by some rude experience of what is best in the long run for all the members; but this judgment will not rarely err from ignorance and weak powers of reasoning. Hence the strangest customs and superstitions, in complete opposition to the true welfare and happiness of mankind, have become all-powerful throughout the world. ${ }^{18}$

Here, 'ignorance and weak powers of reasoning' stymie the ability to determine what will result in 'true welfare and happiness'. This not only suggested that unambiguously stronger powers of reasoning would assess these moral standards differently, and that moral standards are subordinate to assessments of reasoning themselves aligned with welfare. It also implied that moral frameworks did not themselves inflect viable assessments for strange intelligences, if such existed. Regardless, for Darwin, communities of weaker intelligence certainly existed, and a modern like Darwin could assess which of any moralizing customs were more honoured in the breach.

Colonialism made the case more directly:

At the present day civilised nations are everywhere supplanting barbarous nations, excepting where the climate opposes a deadly barrier; and they succeed mainly,

13 Suman Seth, 'Darwin and the ethnologists: liberal racialism and the geological analogy', Historical Studies in the Natural Sciences (2016) 46, pp. 490-527, 524.

14 Seth, op. cit. (13), p. 502.

15 Seth, op. cit. (13), p. 507.

16 Darwin, op. cit. (7), p. 584.

17 Darwin, op. cit. (7), p. 117.

18 Darwin, op. cit. (7), pp. 121-2. 
though not exclusively, through their arts, which are the products of the intellect. It is, therefore, highly probable that with mankind the intellectual faculties have been mainly and gradually perfected through natural selection. ${ }^{19}$

Natural selection perfected intellectual power and intellectual power proved itself primarily through its instrumental force, the bare measure of which between nations was which supplanted the other.

Darwin followed this thought not only through the relationship between nations (civilized or otherwise), but in the details of the inheritance of intellectual powers through a facility with specific arts, and in the judgement of intellectual powers between different individuals in a community: 'If in each grade of society the members were divided into two equal bodies, the one including the intellectually superior and the other the inferior, there can be little doubt that the former would succeed best in all occupations, and rear a greater number of children'. Such are the virtues of purified intellect, when not 'counterbalanced' by other factors 'as by the multiplication of the reckless and improvident'. ${ }^{20}$ Darwin did not consider here whether the multiplication of the 'improvident' might instead produce a different standard of reason, according to which those who multiplied assess themselves to be intellectually superior.

The specific case of moral assessments was more intricate still, simultaneously allowing for relative standards and for moral perfection. Darwin explicitly testified to the complexity of the case, and its relation to reason: 'Ultimately our moral sense or conscience becomes a highly complex sentiment - originating in the social instincts, largely guided by the approbation of our fellow-men, ruled by reason, self-interest, and in later times by deep religious feelings, and confirmed by instruction and habit'. ${ }^{21}$ He famously asserted the possibility of fully alternative moral standards:

I do not wish to maintain that any strictly social animal, if its intellectual faculties were to become as active and as highly developed as in man, would acquire exactly the same moral sense as ours. In the same manner as various animals have some sense of beauty, though they admire widely different objects, so they might have a sense of right and wrong, though led by it to follow widely different lines of conduct. If, for instance, to take an extreme case, men were reared under precisely the same conditions as hive-bees, there can hardly be a doubt that our unmarried females would, like the worker-bees, think it a sacred duty to kill their brothers, and mothers would strive to kill their fertile daughters; and no one would think of interfering. ${ }^{22}$

What I want to point to here is less the relativity of moral standards that this passage suggests, than the calibration of moral sense by comparison to a relativized sense of beauty on the one hand, and to intellectual faculties overall judged along a line of development on the other. Here, the character of the moral sense hovered close to that of the variable sense of the beautiful.

But Darwin did speak of a moral perfection involved when a species or race thrived. Furthermore, in speaking of 'primitives' he took care to emphasize that his moral assessments relied on civilized standards: 'We have now seen that actions are regarded by savages, and were probably so regarded by primeval man, as good or bad, solely as

19 Darwin, op. cit. (7), p. 128.

20 Darwin, op. cit. (7), p. 136.

21 Darwin, op. cit. (7), p. 132.

22 Darwin, op. cit. (7), p. 99. 
they obviously affect the welfare of the tribe, - not that of the species, nor that of an individual member of the tribe'. Welfare grounded moral sense:

This conclusion agrees well with the belief that the so-called moral sense is aboriginally derived from the social instincts, for both relate at first exclusively to the community. The chief causes of the low morality of savages, as judged by our standard, are, firstly, the confinement of sympathy to the same tribe. Secondly, powers of reasoning insufficient to recognise the bearing of many virtues, especially of the self-regarding virtues, on the general welfare of the tribe. ${ }^{23}$

And a narrower scope for sympathy together with simply weaker reasoning powers produced the 'low morality' assessed according to 'our standard'.

On the one hand, Darwin appears to concede a difference in standards, that presumably the 'savage' does not judge their own morality to be low. On the other hand, the possibility of a straightforwardly wider, universalizing scope for sympathy, and for a more powerful reason to correct the bearing of many virtues, suggests that 'our standards' are better ones. In this case, the qualification 'as judged by our standard' emphasized more that the savage could not judge by the civilized standard, over and above establishing any symmetry in which the savage morality stood on a par to a civilized moral sense. There was no question of the savage casting their own judgement on a civilized morality, a morality that might be judged low by that alternative standard. The noble savage whom Wallace attested was alien to Darwin. ${ }^{24}$

Rooting the emergence of moral sense in what promotes the welfare of a group, Darwin opened a standard that allowed for comparison between different moral senses, once again based in and led by reason. Moral perfection was thus not simply a matter of what was best according to one standard among many, but included and depended on what reason judged as most conducive to welfare. Hence the universalizing trend in Darwin's naturalizing account:

the social instincts, which no doubt were acquired by man as by the lower animals for the good of the community, will from the first have given to him some wish to aid his fellows, some feeling of sympathy, and have compelled him to regard their approbation and disapprobation. Such impulses will have served him at a very early period as a rude rule of right and wrong. But as man gradually advanced in intellectual power, and was enabled to trace the more remote consequences of his actions; as he acquired sufficient knowledge to reject baneful customs and superstitions; as he regarded more and more, not only the welfare, but the happiness of his fellow-men; as from habit, following on beneficial experience, instruction and example, his sympathies became more tender and widely diffused, extending to men of all races, to the imbecile, maimed, and other useless members of society, and finally to the lower animals, - so would the standard of his morality rise higher and higher. ${ }^{25}$

Hence an eye to welfare guided by reason and to happiness guided by sympathy deepens and widens the moral sense, extending it to all 'lower' creatures, non-human and human - a

23 Darwin, op. cit. (7), p. 119.

24 Wallace again provides contrast. Note Richards, op. cit. (1), p. 404: 'Wallace concluded The Malay Archipelago (1869) by favorably comparing the state of justice, morality, and individual freedom in societies like that of the Dyaks with the social "barbarism" of Victorian England'. And Richards, op. cit. (1), p. 40: Wallace's 'uneasiness with his 1864 Spencerian interpretation is evident in his response to Spencer's request for a follow-up article on "How to Civilize Savages" for the Reader: "White men in our colonies are too frequently the true savages"'.

25 Darwin, op. cit. (7), pp. 124-5. 
hierarchy that a developed moral sense did not challenge. A collective might make a 'rude' right on this view, to the degree that group welfare and the power for the group to survive and propagate coincided. At the same time, a universal right should prove itself in the furthering of collective might and collective happiness.

If Darwin did not expound on whether a 'savage' standard of intellect might judge civilized reasoning powers to be poor, or whether such an alternative moral standard might assess civilized morality to be low, he did provide examples of negative 'savage' judgements of European beauty, as for instance a reaction to large teeth or advice on how to improve a woman's looks. ${ }^{26}$ The presumption of the universality of reason contrasted with an acknowledged variation in moral standards, nevertheless judged by universalizing sympathy and reason, and moral standards in turn contrasted with those of beauty that now made for more fully alternative judgements of the beautiful, judgements represented as reciprocating the European gaze.

On the score of human difference, Richards repeatedly emphasizes the importance of Darwin's first encounter with the Fuegians. Despite the shock of this experience, in Descent Darwin asserted their recognizable mental powers. Hence, "The Fuegians rank amongst the lowest barbarians; but I was continually struck with surprise how closely the three natives on board H.M.S. "Beagle", who had lived some years in England, and could talk a little English, resembled us in disposition and in most of our mental faculties'. ${ }^{27}$ Darwin repeated the story and extended the statement.

Although the existing races of man differ in many respects, as in colour, hair, shape of skull, proportions of the body, \&c., yet if their whole structure be taken into consideration they are found to resemble each other closely in a multitude of points. Many of these are of so unimportant or of so singular a nature, that it is extremely improbable that they should have been independently acquired by aboriginally distinct species or races. The same remark holds good with equal or greater force with respect to the numerous points of mental similarity between the most distinct races of man. The American aborigines, Negroes and Europeans are as different from each other in mind as any three races that can be named; yet I was incessantly struck, whilst living with the Fuegians on board the 'Beagle,' with the many little traits of character, shewing how similar their minds were to ours; and so it was with a fullblooded negro with whom I happened once to be intimate. ${ }^{28}$

Once again, consider the comparison of traits here, the physical differences belying not only the overall resemblance, but particularly the 'equal or greater force' of the mental similarities.

These instances do not exhaust relevant reflections in Descent. My brief return to them provides some direct evidence of the categories of traits and of different patterns of assessing them. Descent most readily defended a variability in aesthetic assessments, a variability less freely extended to notions of moral progress. At the same time, it took the judgements of what constituted the brute terms of survival or dominance in a given context as unqualified, and posited that the demands for survival rewarded the progressive, higher intellect. Aesthetic assessments were relative (allowing for reciprocating assessments of European or civilized beauty), ethical assessments problematically universal (acknowledged as varying, repeatedly assessed as tending towards a universal), and

26 Darwin, op. cit. (7), pp. 575-6. Richards suggests how hard-won such examples are for Darwin; e.g. Richards, op. cit. (1), pp. 456-61.

27 Darwin, op. cit. (7), p. 65.

28 Darwin, op. cit. (7), p. 178. For John Edmonstone, Darwin’s 'intimate', see Richards, op. cit. (1), p. 16. 
intellectual assessments (particularly those for judging reasoning power) more fully universal, if largely as a matter of presumption.

\section{Wallace's antagonisms}

Even granting that Descent's legacy is much broader than the discourse relating to it, no book can define the discourse in which it participates. The writings of Wallace and Huxley alone make that clear, writings whose role in the production of Descent historical and philosophical scholarship has repeatedly affirmed. ${ }^{29}$

If Wallace's 1890 'Human selection' was a reversal, it was less as a matter of affirming past sexual selection than of anticipating a future female choice, a position that sat well with neither Darwin nor Huxley. Nor did it sit well with George Romanes, the naturalist and founder of the Romanes Lecture series, who was in contentious debate with Wallace. ${ }^{30}$ Richards finds that though the 'overt target' of 'Human selection' was '[Grant] Allen's free-loving "Girl of the Future," its unacknowledged target was Romanes's "woman of the future," handicapped by her evolutionary past, unable to achieve intellectual and social parity with men'.31

Initiating his reflections, Wallace reported,

In one of my latest conversations with Darwin he expressed himself very gloomily on the future of humanity, on the ground that in our modern civilization natural selection had no play, and the fittest did not survive. Those who succeed in the race for wealth are by no means the best or the most intelligent, and it is notorious that our population is more largely renewed in each generation from the lower than from the middle and upper classes. ${ }^{32}$

'Best' and 'most intelligent' are likely understood in conventional senses, but the ambiguity of what they might and could mean raises the question whether they should and can be simultaneously the best in terms of survival value, and intellectual, moral and aesthetic value.

Wallace underscored the distinction between the state of human society and nature more broadly, singling out human ethics and moral feeling:

The survival of the fittest is really the extinction of the unfit. In nature this occurs perpetually on an enormous scale, because, owing to the rapid increase of most organisms, the unfit which are yearly destroyed form a large proportion of those that are born. Under our hitherto imperfect civilization this wholesome process has been checked as regards mankind; but the check has been the result of the development of the higher attributes of our nature. Humanity - the essentially human emotion - has caused us to save the lives of the weak and suffering, of the maimed or imperfect of mind or body. ${ }^{33}$

29 This without further mention of the many evolutionary theorists, commentators, teachers, students, readers and activists who, even in Darwin's lifetime, argued over evolution with little regard to any 'strict' Darwinism. For a relevant discussion if to different ends, see Richards, op. cit. (1), p. 517 and passim.

30 For background on the institution of the Romanes Lecture see James G. Paradis and George Christopher Williams, Evolution and Ethics: T.H. Huxley's Evolution and Ethics with New Essays on Its Victorian and Sociobiological Context, Princeton, NJ: Princeton University Press, 1989, p. 215.

31 Richards, op. cit. (1), p. 509.

32 Alfred Russel Wallace, 'Human selection', in Wallace, Studies Scientific and Social, 2 vols., London: Macmillan and Co., Ltd., 1900, vol. 1, p. 509. Note that Darwin discusses these issues in Descent, detailing 'checks to this downward tendency'. Darwin, op. cit. (7), p. 138 and passim.

33 Wallace, op. cit. (32), p. 526, original emphasis. 
Wallace conceded that this check has 'to some extent been antagonistic to physical and even intellectual race-improvement'. But he emphasized that 'it has improved us morally by the continuous development of the characteristic and crowning grace of our human, as distinguished from our animal nature'. ${ }^{34}$ With the human mind exempted from naturalist explanations, the antagonism between moral improvement on the one hand and physical and intellectual improvement on the other was not for Wallace an opposition or contradiction within one overall process.

That 'we have cleansed the Augean stable of our existing social organization, and have made such arrangements that all shall contribute their share of either physical or mental labour, and that all workers shall reap the full and equal reward of their work', Wallace saw as preconditions for the resolution of such antagonisms. ${ }^{35}$ Thereafter, the freer choice of women would ultimately work to avoid the unfettered growth of the population and select against socially corrosive traits:

The most careful and deliberate choice of partners for life will be inculcated as the highest social duty; while the young women will be so trained as to look with scorn and loathing on all men who in any way wilfully fail in their duty to society - on idlers and malingerers, on drunkards and liars, on the selfish, the cruel, or the vicious. ${ }^{36}$

For Wallace, this extended to characteristics treated as infirmities. In looking towards 'how natural selection will improve the race', Wallace claimed,

The diseased or the weak in intellect would also usually remain unmarried; while those who exhibited any tendency to insanity or to hereditary disease, or who possessed any congenital deformity would in hardly any case find partners, because it would be considered an offence against society to be the means of perpetuating such diseases or imperfections. ${ }^{37}$

In this future society, then, sexual selection would drive and be driven by educated, socially minded choice, and aesthetic traits would become secondary. Sexual selection propels human progress as sexual selection comes to mean selection on the basis of ethics, intellect and vigour. Tellingly, Wallace treated female choice under the heading of 'How natural selection will improve the race'.

Almost explicit in these visions of future worlds, better or worse, was a possible distinction between short-term and long-term strategies. Was it possible that natural selective forces could in the short term (e.g. over a generation) select individuals with a given trait over and above competitors, but that such a trait would be less advantageous to the longer-term survival of the species? For Wallace, were traits promoting the accumulation of wealth examples of these? ${ }^{39}$ Could a society 'vicious and rotten at the core' clearly judge the virtues of any traits? ${ }^{40}$ When looking over the long term, to the future of the

34 Wallace, op. cit. (32), p. 526. For a discussion of Wallace's points here, and their connection to the course of his thought, see Milam, op. cit. (3), esp. pp. 18-22.

35 Wallace, op. cit. (32), p. 517, original emphasis. For further background on the interrelationship of Wallace's views of social progress and evolutionary thought see Greta Jones, 'Alfred Russel Wallace, Robert Owen and the theory of natural selection', BJHS (2002) 35, pp. 73-96.

36 Wallace, op. cit. (32), p. 521.

37 Wallace, op. cit. (32), p. 524.

38 Wallace, op. cit. (32), p. 523.

39 Jones's treatment of this example in Galton draws a striking parallel between the role of wealth in Galton's 'paradox of the heiress' and of the 'selfish gene' in later sociobiology. Jones, op. cit. (8), pp. 188-9.

40 Wallace, op. cit. (32), p. 516. 
species, the articulation of ethical strategies might perhaps be frustrated by overlooking distinctions between local/proximate survival advantage and global/longterm advantage. Did local, generational, advantageous changes accumulate to enduring/global ones?

Wallace's judgements of which proposals for social change might improve society for the better were not free from conundrums. A rotten society could only be transformed to a better one by fundamental change, whether over the short or longer term, judged generationally or by environmental shift. But would such change preserve a vision of or the standards for what constituted the better? Wallace rejected Galtonian proposals, observing that they contribute over time only to the 'perfection in the few' rather than to a higher social average. ${ }^{41}$ Summarizing and evaluating the proposals of Hiram Stanley, Wallace observed that the two great factors which secure perfection in each animal race - sexual selection by which the fit are born, and natural selection by which the fittest survive - both fail in the case of mankind, among whom are hosts of individuals which in any other class of beings would never have been born, or, if born would never survive'. ${ }^{42}$ And in reviewing Allen's 'Girl of the Future', Wallace treated and rejected an unfettered sexual selection on the part of women (not tied to marriage) as the mechanism of improvement. ${ }^{43}$

In none of these proposals did the mechanism itself serve to change the ideal of progress, despite the fact that from the point of view of latter-day claims, it could not be assumed to maintain standards. Alternatively, these proposals presumed not only the survival advantage of a given trait among the individuals or in the generation in question, but that the advantage would persist in successive generations. The selection of the most morally virtuous, the sharpest intellectually, and the strongest physically was presumed to be correlated with how these traits might be judged over the longer term, whether because of a stable enough environment or despite any changes in environment. How might the idea of progress progress?

And yet all these utopian proposals were presented under the shadow of a late Darwinian pessimism and a conservatism espoused by Romanes. Here, then, there is a rhetorical edge to sexual selection falling under the heading of natural selection, of proposals promoting sexual selection as key to generalized human improvement. These answered concerns of the imagined decline engendered by humanity transcending natural selection with the mechanism of less restrained, more socially conscious sexual selection: as sexual selection became 'social duty', sexual selection aligned with contemporaneous standards of health, probity and intellect. But how would that decline be conceived in terms of the natural and selective forces governing the traits used to measure that decline? And what room was there for the aesthetic traits that for Darwin were inseparable from sexual selection?

41 Wallace, op. cit. (32), p. 513. Recall Darwin: 'A most important obstacle in civilised countries to an increase in the number of men of a superior class has been strongly insisted on by Mr Greg and Mr Galton, namely, the fact that the very poor and reckless, who are often degraded by vice, almost invariably marry early, whilst the careful and frugal, who are generally otherwise virtuous, marry late in life, so that they may be able to support themselves and their children in comfort'. Darwin, op. cit. (7), p. 138. From the point of view of advantageous characters, or from a standard of differentiation and specialization (given that new classes might arise), does this constitute decline or progress?

42 Wallace, op. cit. (32), p. 513.

43 For extended discussion of eugenic progressive discourse in relation to the New Woman, see Angelique Richardson, Love and Eugenics in the Late Nineteenth Century: Rational Reproduction and the New Woman, Oxford and New York: Oxford University Press, 2003. 


\section{'Evolution and ethics' in the legacy of Descent}

Three years after Wallace's essay, in 1893, Huxley's 'Evolution and ethics' dramatized questions of the conceptual dilemmas entailed by totalizing explanations on the one hand and the variability of moral standards on the other. ${ }^{44}$ In a letter to his son-in-law a few days before the Romanes Lecture, he referred to the upcoming performance as a 'regular eggdance': 'That I should discourse on Ethics to the University of Oxford and say all I want to say, without a word anybody can quarrel with, is decidedly the most piquant occurrence in my career'. ${ }^{45}$ In accepting that 'no allusion shall be made to religion or politics', he explained in another letter later that year, 'I had to make my omelette without breaking any of those eggs, and the task was not easy'. ${ }^{46}$ Whatever compelled his egg-dance, the resulting character of his claims was simultaneously abstract and urgently intoned claims which concern 'what we call goodness or virtue' and how it 'repudiates the gladiatorial theory of existence'. ${ }^{47}$

Huxley argued that the 'influence' of virtue 'is directed, not so much to the survival of the fittest, as to the fitting of as many as possible to survive'. To his mind, this undercut the 'analogy of cosmic nature to society' posited in and through the 'fanatical individualism' of the period. In a kind of summary judgement suggesting exasperation with views hardly distant from his own circles of friendship and acquaintance, he declared, 'Let us understand, once for all, that the ethical progress of society depends, not on imitating the cosmic process, still less in running away from it, but in combating it'. He recognized that such a claim might seem 'audacious' but saw its apparent hubris tempered by the recognition that '[t]he history of civilization details the steps by which men have succeeded in building up an artificial world within the cosmos'. This replacement of first nature by second depended on consonance between human and universal energies allowing the 'microcosm' or the 'dwarf' to overcome the 'macrocosm' or the 'titan'. He hazarded in this a faint view of a further mastery of nature, that 'a right comprehension of the process of life and of the means of influencing its manifestations is only just dawning upon us'. In the future, such comprehension would 'work as great a revolution in the sphere of practice', as with the physical sciences ('Astronomy, Physics, Chemistry') which had advanced so far as to become 'an important factor in human affairs', ${ }^{48}$

Though the importance of Darwinian evolution to such arguments is evident, the role specifically of Descent calls for (re)clarification. James Paradis observes of the response to the lecture, 'Much of the commentary of Huxley's own time concerned the apparent shift in Huxley's thought'. ${ }^{49}$ Modern historical scholarship has also taken up variations of this question, attending to Huxley's meaning(s) and aims in the lecture. In doing so, the scholarship makes a case for 'Evolution and ethics' as part of the legacy of Descent, or deeply tied to it.

Reading through Huxley's political commitments and his prior writings, Helfand finds that 'Evolution and ethics' reflects Huxley's consistent positions, encapsulating some of Huxley's long-term social and political engagements. Helfand corrects the scholarship

44 For correspondence on the lecture series itself and Huxley's involvement see Ethel Romanes, The Life and Letters of George John Romanes, London: Longmans, Green, and Co., 1896, p. 291 and passim; and Leonard Huxley, Life and Letters of Thomas Henry Huxley, vol. 3, London: Macmillan and Co., Ltd, 1908, esp. Chapters 11 and 12.

45 Huxley, op. cit. (44), p. 296.

46 T.H. Huxley to Professor Seth, 27 October 1893, and T.H. Huxley to John Skelton, 15 July 1893, in Huxley, op. cit. (44), pp. 300-2. For the exchange with Andrew Seth see David Goslee, 'Evolution, ethics, and equivocation: T.H. Huxley's conflicted legacy', Zygon (2004) 39(1), pp. 137-60, 148-9.

47 T.H. Huxley, Evolution \& Ethics and Other Essays, London: Macmillan and Co., 1894, p. 82.

48 Huxley, op. cit. (47), pp. 83-4.

49 Paradis and Williams, op. cit. (30), p. 219. 
regarding Huxley's lecture as 'limiting and depoliticizing the authority of evolutionary science'. Rather, he argues, Huxley's

main purpose was to deny the authority of evolutionary science to both the individualist ethic of Spencer and the land-socialist cause of George and Wallace, while using that authority to bolster the specific policies he supported. By claiming that those who held to the 'ethics of evolution' were mistaken in their belief that the evolutionary process of nature was also an ethical one [as Wallace's future natural/sexual selection would be], he denied scientific authority to both Spencer and the radicals. ${ }^{50}$

Helfand refers to the lecture as a 'masterpiece of concealed debate' - so concealed as to be productive of misreadings ever after. ${ }^{51}$

Though emphasizing the significance of Helfand's work, Paradis regards it as reductionist and sees 'Evolution and ethics' and the 'Prolegomena' instead as 'preeminently Huxley's final defence of Victorian naturalistic thought'. ${ }^{52}$ Towards that defence, Paradis observes that 'Huxley must have returned to the Descent of Man as he was writing Evolution and Ethics'. The shared issues Paradis identifies in the texts are 'the Malthusian pressures, the unity of human and animal faculties, the instinctual basis and utility of morality, behavioral mimicry, and sympathy'.53

Richards's own treatment of 'Evolution and ethics' sets Huxley's address in the context of Wallace's differences with Romanes and Huxley. Reflecting on Helfand's characterization and assessing the literature since his analysis, she points to how this scholarship revises the 'time-honored interpretation' which regarded the lecture as 'Huxley's celebrated stand against the laissez-faire "oughts" of the evolutionary ethics of Spencer and the new-christened "Social Darwinists". ${ }^{54}$ Richards demonstrates that earlier analyses omitted the degree to which Huxley resisted Wallace and other utopian alliance as a result of his own resistance to female choice and any reliance on the 'New Woman'. 55 'Evolution and ethics' formed part of a contest over the meaning both of Darwinism and of progress, as Richards demonstrated in her attempt 'to restore what these [Helfand and post-Helfand] revisions overlook: the gender and sexual dimensions of the Romanes Lecture and its implications for sexual selection'. ${ }^{56}$ Huxley's address

sought to turn the tables on Wallace by reinstating the Darwinian struggle for existence as essential to human progress, while denying biological and moral legitimacy to those applications of artificial selection and female choice that underlay Wallace's advocacy of woman's powerful and responsible role in a socialist society. It counterpoised ethical man to Wallace's morally superior, socialist woman of the future. ${ }^{57}$

These fights over natural and sexual selection in the wake of Descent produced a retort by Huxley that denied the radical ethical power of female choice in the denial of ethical selection overall.

50 Michael S. Helfand, “Evolution and ethics”: The politics of evolution and the evolution of politics', Victorian Studies (Winter 1977) 20, pp. 159-77, 177.

51 Helfand, op. cit. (50), p. 160.

52 Paradis and Williams, op. cit. (30), pp. 5, 8.

53 Paradis and Williams, op. cit. (30), p. 28.

54 Richards, op. cit. (1), pp. 511-12.

55 For further discussion of this resistance to radical thought, and to aestheticism, in relation to Descent and scientific naturalism, see Gowan Dawson, Darwin, Literature, and Victorian Respectability, Cambridge: Cambridge University Press, 2007.

56 Richards, op. cit. (1), p. 512.

57 Richards, op. cit. (1), p. 514. 


\section{Huxley's antagonisms, and 'Prolegomena' as sequel}

Responding to critiques of his lecture, including those of St George Mivart and Spencer, the following year Huxley provided a 'Prolegomena' to his Romanes Lecture. In it, he exhibited the figure of a garden cultivated out of the state of nature. Its cultivation and preservation required resisting some forces of nature in order to nurture others. As a gardener might battle with certain tendencies of plants and with the nature corrosive to the garden, human society warred with the cosmos, including itself within that cosmos. Civilization worked to curb the universality of natural selection in the field of human life and society, just as the gardener produced conditions keeping natural selection in sustained abeyance.

Huxley paid attention to a potential logical absurdity mooted in the lecture, of the relation of microcosmos to macrocosmos:

No doubt, it may be properly urged that the operation of human energy and intelligence, which has brought into existence and maintains the garden, by what I have called 'the horticultural process,' is, strictly speaking, part and parcel of the cosmic process. And no one could more readily agree to that proposition than I.

Here he saw the possibility of a paradox, that if

it is urged that ... the cosmic process cannot be in antagonism with that horticultural process which is part of itself - I can only reply, that if the conclusion that the two are antagonistic is logically absurd, I am sorry for logic, because, as we have seen, the fact is so. ${ }^{58}$

His critical response in correspondence with Andrew Seth, who would review the text and republish the review in his Man's Place in the Cosmos, was still less patient:

I really have been unable to understand what my critics have been dreaming of when they raise the objection that the ethical process being part of the cosmic process cannot be opposed to it.

They might as well say that artifice does not oppose nature, because it is part of nature in the broadest sense. ${ }^{59}$

In a footnote to the 'Prolegomena', Huxley simultaneously tightened his point but also demonstrated the difficulty of it in appealing to what he saw as a simplifying analogy: 'When a man lays hold of the two ends of a piece of string and pulls them, with intent to break it, the right arm is certainly exerted in antagonism to the left arm; yet both arms derive their energy from the same original source'. The right arm of the horticultural process struggled against the left arm of the cosmic process, both of which derived their powers from the universe. Or, to pare down Huxley's analogy further, clasp the fingers of each hand together directly rather than pulling on a string.

But then, what was this cosmic process, if its 'characteristic feature' was the 'intense and unceasing competition of the struggle for existence'? ${ }^{60}$ Was it different from the 'cosmic evolution' Huxley appealed to in the same lecture? Did that right arm threaten to become the entire body, in conjunction with a cosmic process understood increasingly through the dominance of natural selection? In turn, beyond Huxley and his reserve

58 Huxley, op. cit. (47), pp. 11-12.

59 Huxley, op. cit. (44), p. 300.

60 Huxley, op. cit. (47), p. 13. 
over sexual selection, when and to what extent was the horticultural process identifiable with or itself figured by mate choice, making civilization or its advance possible, or explaining human racial differentiation? How might responses to these questions depend on whether sexual selection signifies modification rather than improvement? Could an arm struggle against itself?

As with the Romanes Lecture, historical scholarship portrays the arguments and aims of Huxley's 'Prolegomena' varyingly. According to Helfand, the 'Prolegomena' 'further explained the contradiction of his absolutist yet naturalistic ethic', and 'clarified his attack on those who wished to legislate cooperation in society and reaffirmed the value of struggle within society'. ${ }^{61}$ Paradis finds that the lecture and its prolegomena were 'best considered as a single work', where 'humanist themes of textual analysis and scholarship occupy Huxley in the Romanes Lecture, and naturalistic speculation occupies him in the "Prolegomena". Thus the later text 'develops more forcefully the dichotomy between the "state of nature" and the "state of art," between the "cosmic process" and "ethical process," as the central paradox of human existence'. ${ }^{62}$ Moreover, he contends that

Huxley wrote the two essays of Evolution and Ethics [the lecture and 'Prolegomena'] in imitation of Malthus for precisely the reasons that Malthus had written An Essay on the Principle of Population (1798) - to refute, by reference to natural material and instinctual constraints, the romantic a priori arguments of the social idealists. ${ }^{63}$

David Goslee, by contrast, argues that 'Huxley's reviewers forced him into qualifications that rendered his Prolegomena less an introduction than a rebuttal to the original essay', the former leaning toward a 'covert idealism' and the latter toward a 'covert naturalism'. ${ }^{64}$

Such readings point to historical erasures, the degree to which past fields of 'meaning and purpose' have largely vanished. They indicate some of Huxley's motivations and intended meanings in light of his long-standing commitments, or in light of his more tortured responses to contemporaneous reviews of his arguments. They also suggest the multiplicity of meanings and motivations at play in the texts, for Huxley and his readers.

Whether or not Huxley shifted his position on the antagonism between ethical and cosmic processes, the 'Prolegomena' was itself an early instance of deliberation over the antagonisms of 'Evolution and ethics', and the measures of progress and decline posited by Darwin and Wallace. These continued to be a subject of discussion in reflections on Huxley's arguments in subsequent decades, while recognition of the conflict with the radicals and defences of past naturalisms began to disappear, aesthetics playing a less primary role.

\section{Evolutionary antagonisms in science-ethics discourse and debates of later generations}

This overt legacy of questioning, often presuming the universality of intellectual assessments, celebrated Huxley as getting right the evolutionary historicity/variability of moral assessments, or indicted him as getting it wrong. The emergence of eugenic conceptions and dysgenic fears of civilizational decline, of an antisocial social Darwinism or a cooperative natural selection, also helped define what might constitute scientific quietism or

61 Helfand, op. cit. (50), p. 175.

62 Paradis in Paradis and Williams, op. cit. (30), pp. 217-18.

63 Paradis in Paradis and Williams, op. cit. (30), pp. 6-7.

64 Goslee, op. cit. (46), p. 139. 
activism in relation to potential social change. ${ }^{65}$ The ongoing attestation of Huxley's lecture suggests ways that its conceptual entanglements remained active, helping to clarify some of the presumptions and overt distinctions in evolutionary discourse. I give only a brief, fragmented sketch here, limiting more extended explication to moments in which the question of assessments by and of (Descent's) different categories of traits is close to the surface.

'Evolution and ethics' became a source text on scientific and wider deliberations over the relationship of the two terms of the title, as well as their relation to progress and the meaning of evolution. So, in his own Romanes Lecture of 1920, 'The idea of progress', the dean of St Paul's, William Ralph Inge, observed to his audience,

in this place we are not likely to forget the second Romanes Lecture, when Professor Huxley astonished his friends and opponents alike by throwing down the gauntlet in the face of Nature, and bidding mankind to find salvation by accepting for itself the position which the early Christian writer Hippolytus gives as a definition of the Devil - 'he who resists the cosmic process'. ${ }^{66}$

Peter Bowler has examined the work of the 'Gloomy Dean' in the broader context of Anglican modernism, the dean's views exemplary of the pro-scientific dimensions of that movement. ${ }^{67}$ Together with the views of Bertrand Russell, Huxley demonstrated to Inge's satisfaction 'that the alleged law of progress has no scientific basis whatever' ${ }^{68}$

Three years later, in J.B.S. Haldane's Daedalus; or, Science and the Future, Huxley's lecture provided a brief but potent allusion: 'The time has gone by when a Huxley could believe that while science might indeed remould traditional mythology, traditional morals were impregnable and sacrosanct to it'. ${ }^{69}$ This rapid reading of Huxley ignored not only the fact of Huxley's opponents but also the degree to which even a naturalizing view of morality like Darwin's could tend to enforce a universalizing morality guided by a stark notion of reasoning power.

Four years after Daedalus, Inge's October 1927 lecture 'Scientific ethics' prompted a retort by Haldane. Inge again took up Huxley's views from the latter's 'famous Romanes lecture', partly framing his remarks as a response to the 'radical pessimism' he found in Huxley's arguments. ${ }^{70}$ As Wallace had sought to counter the late Darwin's pessimism, Inge attempted to counter Huxley. ${ }^{71}$

Inge returned to the terms of Huxley's antagonism of cosmic and civilizing processes, claiming that the problem with Huxley's formulation was the pernicious play of ideas of progress which had 'deeply infected the science of the nineteenth century, spoiling the philosophy of Herbert Spencer, and injuring that of Darwin himself. ${ }^{72}$ If

65 Here again we might see another distinction between Darwin and Wallace. See Jones, op. cit. (35), e.g. pp. 73-5.

66 W.R. Inge, The Idea of Progress, Delivered in the Sheldonian Theatre 27 May, 1920, Oxford: Clarendon Press, 1920, p. 14. He argued directly thereafter, 'The revolt was not in reality so sudden as some of Huxley's hearers supposed.'

67 Peter Bowler, Reconciling Science and Religion: The Debate in the Early-Twentieth-Century Britain, Chicago: The University of Chicago Press, 2001.

68 Inge, op. cit. (66), p. 16.

69 J.B.S. Haldane, Daedalus; or, Science and the Future; a Paper Read to the Heretics, Cambridge, on February 4th, 1923, New York: E.P. Dutton, 1924, p. 90.

70 William Ralph Inge, Scientific Ethics: The Norman Lockyer Lecture 1927, London: British Science Guild, 1927, p. 6. Peter Bowler has examined the work of the 'Gloomy Dean' in the broader context of Anglican modernism, the dean's views exemplary of the pro-scientific dimensions of that movement. See Bowler, op. cit. (67).

71 Inge, op. cit. (70), p. 6.

72 Inge, op. cit. (70), p. 7. 
anything, his emphasis suggested more a critique of Wallace, whom he (also) did not name, than of Huxley, whose pleas for the unexceptionality of humanity Inge did not treat. 'But the main error', Inge wrote, 'is to consider the cosmic process apart from man'. ${ }^{73}$

Inge offered six ways that science might in future yield "positive contributions to ethics'. ${ }^{74}$ Science was called upon to chastise specific trends within or intersecting with the religious community. Inge's second and third propositions approved of the action of science in providing resistance to concrete characterizations of God, and to belief in superstition. The first, fourth and fifth likewise looked to science for an improving, enlightening influence: in the accuracy of public opinion, in the potential 'rational treatment' of children, in the better treatment of animals ${ }^{75}$ and a resistance to 'defacing the surface of the planet, ravaging its natural resources, destroying some beautiful species, which, once gone, can never be replaced'. ${ }^{76}$ The sixth and last 'contribution' saw Inge's endorsement of eugenics. Not going so far as to approve of sterilization programmes, Inge nevertheless cited the case of California as hopeful for the future of pro-eugenic/scientific legislation and invoked recent US anti-immigration measures and the race theories of Grant and Stoddard still more approvingly.

Haldane took Inge to task for 'Scientific ethics' in his April 1928 lecture 'Science and ethics. ${ }^{77}$ Haldane did not here provide any direct alternative reading of Huxley. His terms and figures nevertheless were not only consonant with Huxley's, but brought out vividly the question of the differences between moral and intellectual standards. To Inge's six propositions before the Guild, Haldane returned five different ways in which science 'impinges upon ethics', propositions resonant with wider evolutionary discourse thereafter. $^{78}$

First, science created new ethical situations - e.g. new interventions were possible in a world drawn closer together by technological developments. Second, scientific action led to 'unexpected consequences'. 79 The inability to know the consequences of eugenic interventions (whether in relation to parenting prohibitions or immigration policy) presently at best advised inaction and, if anything, justified the 'Golden Rule' as the most clearly and broadly hygienic, an articulation of which Descent had also endorsed. ${ }^{80}$ Third, science changes cosmology or mythology and, as a matter of this alone, the view of interaction with the world. Implicit in these arguments was the belief that duties to one another should harmonize with the results of a scientific world view. ${ }^{81}$ Relatedly, fourth, anthropology, as a scientific study of human culture, would itself produce a comparative ethics. The fifth impingement concerned how scientists already behaved in the world, as professionals, advancing the image of rational action in one's work, encouraging the wider

73 Inge, op. cit. (70), p. 7. There is a potential distinction here, however, between treating humanity apart from the cosmic process (something Huxley rejected) and treating the cosmic process apart from humanity (which Inge claimed was the error).

74 Inge, op. cit. (70), p. 8.

75 Specifically in light of 'Darwin's discoveries in the origin of species', that 'the lower animals are literally our distant cousins'. Inge, op. cit. (70), p. 11.

76 Inge, op. cit. (70), p. 13. Inge concluded, 'and generally behaving like ill-conditioned savages'.

77 J.B.S. Haldane, 'Science and ethics', Harper's (June 1928) 157, pp. 1-10, excerpt reprinted from Haldane, Science and Ethics: Conway Memorial Lecture delivered at Essex Hall on April 18, 1928, London: Watts \& Co., 1928.

78 Haldane, op. cit. (77), p. 1.

79 Haldane, op. cit. (77), p. 1.

80 Haldane, op. cit. (77), p. 2. Note also Darwin, op. cit. (7), p. 126.

81 This harmonization is, however, underdetermined, allowing for different views of the relation between science and ethics. See Haldane, op. cit. (77), p. 1. 
'adoption of a scientific point of view', for everyone, including scientists in their fuller lives, as well as for the lay activity of deans. ${ }^{82}$

If science enriched the ethical universe by complicating life, it enriched it so much as to outstrip the ethical world from which it emerged: 'applied science has created so many new moral problems that the morality of our ancestors must in any case be drastically revised'. ${ }^{83}$ Echoing a declaration of the elder Huxley, an echo with its own echoes, Haldane declared that science had produced a crisis of morals and ethics. He looked forward to a future moment consummating efforts 'to apply scientific method both to individual moral problems and to the problem of morality itself. Such a consummation 'represents the unification of human effort, the marriage of the mind and the heart, the moralization of science, and the rationalization of ethics'. ${ }^{84}$

In 'Science and ethics', what the issue of eugenics signalled and reinforced most clearly was that the revision of morality had not yet been carried out. It was here that the differing variability of types of traits, and particularly intellectual ones, came out most explicitly:

[Inge] congratulates the United States on stopping the flood of immigration from Southern and Eastern Europe. Now politically this may be a wise measure. The countrymen of Lenin and Mussolini probably do not make such good Babbitts as the races of Northwestern Europe. And on the whole, they do not score as highly in so-called intelligence tests of the particular type current in the United States ... But even if the average Italian is stupider than the average Swede - which may be the case - either or both of the following facts may still be true: genius of certain types may be commoner among Italians than Swedes, and as the result of crossing these two peoples a type in many ways finer than either may be produced. This is certainly the general rule with animals and plants, and history suggests that it is true of men. ${ }^{85}$

Haldane's criticism recognized different types of intelligence, while at the same time treating these types as commensurate enough to be weighed together ('a type in many ways finer than either may be produced'). This leant more towards Darwinian treatments of morality, with its qualified universals, a morality also guided by intellect, and not so variable as that sense of the beautiful spoken of as unqualified, defended as relative, and bracketed here.

Haldane explicitly compared the heritability of physical, moral and intellectual traits, underscoring their different variability, echoing Wallace. Referring disapprovingly to '[o] ther self-styled eugenists', he noted that these 'suppose that moral qualities are inherited to much the same degree as physical and intellectual'. Though granting that 'brothers resemble one another in these respects about as much as in physical and intellectual qualities', Haldane attributed this primarily to environmental factors. 'It is, after all, a matter of common sense that it is easier to make a bad boy good than a stupid boy clever' ${ }^{86}$

There was as little apology here for 'stupid' as there might have been for 'weak' or 'bad' or 'ugly'. But 'stupid' would not be redeemed as intelligent through a more perfect empathy and understanding, or through the eye of a beholder. Haldane did not tarry

82 The Mertonian ring of Haldane's impingements merits more discussion. For Merton's acknowledgement of Haldane see Robert K. Merton, 'Science and the social order', in Merton, The Sociology of Science, Chicago: The University of Chicago Press, 1973 (first published 1938), p. 262. See also Merton, 'Science and the social order', in the same volume, pp. 267-8.

83 Haldane, op. cit. (77), p. 9.

84 Haldane, op. cit. (77), p. 10.

85 Haldane, op. cit. (77), pp. 4-5.

86 Haldane, op. cit. (77), p. 6. 
with the character and rhythms of the relationship between the heritability of traits on the one hand and the development of (and shifts in) standards evaluating manifestations of those traits on the other. He agreed with Inge that ' $[\mathrm{s}]$ cience does not, of course, support the doctrine of human perfectibility'. And then directly added, 'But it does tend to uphold the view that this doctrine is much more nearly true in the sphere of ethics than in that of intellect - in other words, that mankind is more readily modified by moral than intellectual education'. ${ }^{87}$

Education changes moral nature, and selection may possibly change intellectual nature. But this possibility conduces to a treatment of intelligence as universal, despite the judgement that its traits are heritable and its striking manifestations (genius) are variable. Haldane cast doubt on intellectual perfectability, not because a more perfect or finer intelligence did not exist, but because intellectual education was ineffective. He cautioned, 'We do not yet know enough about the inheritance of mental ability to be able to say that a few generations of selection against it would weed it out to an appreciable extent' ${ }^{88}$

Roughly a decade later, in his 1939 'The uniqueness of man', Julian Huxley recalled 'Evolution and ethics', finding in his grandfather's 'famous Romanes lecture' the sentiment that humans must 'be brave and face the fact and the consequences of our uniqueness'. ${ }^{89}$ The Julian Huxley of the 1930s differed from the Julian Huxley of the 1910s over the question of female choice. The later Julian Huxley subsumed sexual selection under natural selection, and in so doing articulated a conceptual possibility not adopted by either his grandfather or Darwin. For this later Huxley, as a result, selection tended to align evolutionary progress, whatever such progress might mean (and the younger Huxley was not silent on this matter), with aesthetic sense, resulting in a notion perhaps of aesthetic progress.

Explicitly, he extended the alignment further. Tying his grandfather's views to the more recent claims of the philosopher Walter Goodnow Everett on human uniqueness, he qualified, 'but I would suggest that the antinomy between man and the universe is not quite so sharp as they have made out'. ${ }^{90}$ According to Julian Huxley, 'So far as our knowledge goes, human mind and personality are unique and constitute the highest product yet achieved by the cosmos. ${ }^{91}$ As such, humanity could align standards by dictating them:

In the perspective of biology, our business in the world is seen to be the imposition of the best and most enduring of our human standards upon ourselves and our planet. The enjoyment of beauty and interest, the achievement of goodness and efficiency, the enhancement of life and its variety - these are the harvest which our human uniqueness should be called upon to yield. ${ }^{92}$

For Wallace in his 'Human selection' essay, moral feeling had checked natural selection with some cost to moral and intellectual progress, a cost that a future sexual selection based on other than aesthetic choices might address. For Julian Huxley, human mind and personality themselves became a culminating evolutionary product, determining the standards by which to take stock of the progress that produced them and produce the progress to come.

During the war, deliberation over 'Evolution and ethics' continued. C.H. Waddington's 'Science and ethics' recurred to it. Arguing against the need for an external standard of

87 Haldane, op. cit. (77), p. 6.

88 Haldane, op. cit. (77), p. 5. He adds here, 'though this may quite probably be the case'.

89 Julian Huxley, The Uniqueness of Man, London: Chatto \& Windus, 1943, p. 31.

90 Huxley, op. cit. (89), pp. 31-2.

91 Huxley, op. cit. (89), p. 32.

92 Huxley, op. cit. (89), p. 33. 
the 'good' apart from evolution, he claimed that 'a society implies a direction of development into a society which could include the earlier stage, as, to take an exaggerated example, American culture can include that of the Red Indian, but not vice versa'. Taking a notion of a social 'direction of change' as granted, Waddington argued contra Huxley that 'the general character of the cosmic process, or as we should now say, of the course of evolution, does not seem so morally offensive that we cannot accept it'. ${ }^{93}$

The essay invited responses from scholars of theology, psychology and the physical and life sciences, including W.R. Matthews (dean of St Paul's after Inge), Karin Stephen, Susan Stebbing, Joseph Needham, Herbert Dingle and J.D. Bernal, together with Julian Huxley and Haldane. Critique of Waddington's reply to T.H. Huxley reappeared across several of the responses, as did invocation of Spencer on progress and evolution. Not exclusively by way of Waddington's assertion of the possibility of a science of ethics, the debate took up the question of the relationship between the intellectual and the ethical. Responses arguing for the social and historical variability of ethics at the same time queried or asserted a universalist, evolutionary guideline. Though many responses questioned the nature of moral standards offered by Waddington's evolutionary/social direction, the nature of intellectual standards received no corresponding treatment.

By this point, Haldane endorsed the senior Huxley's antagonistic characterizations, over and above Haldane's own contemporaries, reading those antagonisms in dialectical terms: 'the cosmic process, which was responsible for human evolution, negates itself by generating the ethical process'. On this basis, Haldane advanced an ethical dilemma similar to T.H. Huxley's: 'There is a real contradiction, which will be resolved when men not only realize, as eugenists do, that they ought to control their own evolution, but also possess, as they do not at present, the knowledge and technique necessary for this control'. ${ }^{94}$ The antagonisms which on Helfand's readings diffused the threat of Wallace's socialism became a part of the conceptual armoury of Haldane's Marxism.

Though he invoked his 'Uniqueness of man', Julian Huxley's response to Waddington did not directly refer to his grandfather. In the final chapter of the 1942 Evolution: The Modern Synthesis, he returned, however, to Daedalus and cited his grandfather's Romanes Lecture. With regard to the former, he noted a point concerning the control of evolution displayed in varied terms thereafter: "if we could discover how to implement the suggestion of Haldane in his Daedalus and reproduce our species solely from selected germinal tissuecultures, then all kinds of new possibilities would emerge'. ${ }^{95}$ And the following year provided Julian Huxley the occasion for a longer reflection on 'Evolution and ethics.' For the fiftieth anniversary of his grandfather's lecture, Julian Huxley delivered his own Romanes Lecture, 'Evolutionary ethics', articulating views largely consonant with the sentiment expressed by Haldane's remark on T.H. Huxley in Daedalus. He judged the senior Huxley's defence of ethics to be based on an outdated moral universe, the spread of ethical relativism and fascism demonstrating how untenable his grandfather's views had since become. ${ }^{96}$

\section{Conclusion}

Evolutionists and scholars of varied disciplines continued to take up 'Evolution and ethics' in the years thereafter. The essay was reproduced in volumes on evolution and ethics, sometimes with the 'Prolegomena' (as with texts reproducing both of the Huxley

93 C.H. Waddington, Science and Ethics, an Essay by C.H. Waddington, together with a Discussion between the Author and E.W. Barnes [and others], London: George Allen \& Unwin Ltd, 1942, pp. 17-18.

94 Waddington, op. cit. (93), p. 43.

95 Julian Huxley, Evolution: The Modern Synthesis, London: George Allen \& Unwin Ltd, 1948 (first published 1942), p. 573.

96 T.H. Huxley and Julian Huxley, Evolution and Ethics: 1893-1943, London: The Pilot Press Ltd, 1947, pp. 103-5, 
Romanes Lectures), volumes including disciplinary divisions and responses. ${ }^{97}$ As the work of Evelleen Richards, Robert Richards and Milam suggests, such considerations cannot be relegated to a discourse somehow distinct from scientific practice. ${ }^{98}$ And in view of scholarship canvassed here, by way of 'Evolution and ethics', Descent echoes through this evolutionary discourse.

From the retrospective gaze offered by this specific legacy, however, distinctions and tensions active in Descent not only echoed, but resonated. Judged by the response to 'Evolution and ethics', the categories and varying assessments made of ethical and intellectual traits remained consonant with Darwin's argumentation. In the progressive concerns of this discourse, mate/sexual selection was often theorized in relation to virtues other than aesthetic ones, subsuming sexual to natural selection, whether as an explicit matter, as with Wallace, or as a function of eugenic arguments like Haldane's. Together with T.H. Huxley's pointed silence on sexual selection in the response of 'Evolution and ethics' to Descent and to Wallace, aesthetic traits could be treated as inessential to the mechanism of evolutionary progress or development. This even as Julian Huxley would characterize the culmination of the progress he endorsed in aesthetic terms.

But if that specific legacy at least partly silenced Darwin's treatment of aesthetics in sexual selection, it shared silences with Descent over questions raised by evolutionary discourse. What explained the difference in assessments of different traits by evolutionary lights? Would these differences render intelligence a less variable quality, one less or differently subject to natural selection than beauty, less subject to branching, regardless of whether the late Wallace was right or wrong about the special status of human mind? And if that intellect was regarded as a tool that might be used for the determination of truth and, rejecting Wallace's position, there was no evident transcendental guide to that determination - did truth itself become subject to evolutionary variation, to non-progressive evolutionary logic? Did this render truth pluralistic, or could a provision be found somehow allowing for the immanence and universality of truth simultaneously? Was there any stable standard or provision for intellectual verdicts on survival advantages of different traits in given environments over a given period of time?

The evolving human mind might itself branch, but not apparently from any aesthetic character of a larger brain, and not in such a way as to produce incommensurate intelligences or those that might evaluate survival advantage or social welfare differently. In the context of a self-consciously globalizing humanity, an entity Julian Huxley asserted and Haldane posited, where humanity increasingly distinguished itself by its ability to reconstruct itself and its environment, survival advantage appeared to be rendered in more absolutist, and less environmentally qualified, terms - a potential consequence of Wallace's prior claims for human exceptionality, or of Darwin or T.H. Huxley's claims for colonization. ${ }^{99}$

Would further progress from T.H. Huxley's outdated moral universe endorse not only the assessment of Julian Huxley's 'best and most enduring of human standards' to date, but also the standards for assessing it? Did Darwin's claim that 'the intellectual faculties have been mainly and gradually perfected through natural selection' demand that the assessment of the tendency of that perfection remain fixed? As Julian Huxley himself emphasized and the later 'dilemmas' of sociobiology would suggest, it was increasingly

97 Huxley and Huxley, op. cit. (96), is itself one example (published with 'Prolegomena'). A further example is Doris V. Nitecki and Matthew H. Nitecki, Evolutionary Ethics, New York: State University of New York, 1993 (without 'Prolegomena'). See also Paradis and Williams, op. cit. (30).

98 See Robert J. Richards, 'Darwin's place in the history of thought: a reevaluation', Proceedings of the National Academy of Sciences of the USA (2009) 106, pp. 10056-60, esp. 10056.

99 For connections between garden and colony see T.H. Huxley, op. cit. (47), e.g. pp. 9, 16-20. 
difficult to ignore that standards for making judgements were themselves subject to evolutionary change. This troubled several of Waddington's respondents, who sought to find a universal ethical guideline - whether one fixed in time or, as with Darwin, one provided by a universalization of ethics over time. But as Haldane's response to Inge suggested, even when the possibility of different types of mind might surface in this discourse, the guideline of a finer mind could be presumed or evoked rather than problematized.

Acknowledgements. I would like to thank the participants of the Descent of Darwin workshop and especially its co-organizers Erika Milam and Suman Seth for the generosity of their ideas and for their critical comments and insights through the varied iterations of this work. My thanks go as well to Ana Rosen Vollmar for her readings and for extended discussions, to anonymous readers for their feedback, and to Simon Werrett for his patient editorial supervision throughout the revision process.

Cite this article: Zakariya N (2021). Evolutionary antagonisms and the progress of three categories of traits. BJHS Themes 6, 179-200. https://doi.org/10.1017/bjt.2021.8 